\title{
Effectiveness Measurement Methods for the Application of Design Thinking Approach
}

\section{A design thinking megközelítés alkalmazhatóságának hatékonyságmérési módszerei}

The design thinking approach is a widely applied mindset in businesses and began to become more and more popular in public services. Nevertheless, there are market segments, and players do not prefer to employ the tools and the methods offered by this fresh concept. After detailing the characteristics of the design thinking approach, the paper tends to provide possible solutions for its intensive spread in all sectors by offering concrete options for defining the benefits expressed numerically. Following a short conceptual clarification, the paper details two main issues. The first main point is: does the effectiveness expressed numerically influence decision-makers in facilitating an overall spread of design thinking approach? Secondly, three suitable measurement methods are introduced for evaluating the effectiveness with a comparison of their main features. Finally, the authors draw conclusions and evaluate the research question.

JEL classification: A12, B49, D40, D47, D70, D79, L11, L20, L80, M10, M20, M30, O10, O20, O30

Keywords: design thinking, effectiveness, service design, metrics (for design thinking), data envelopment analysis, cost-effectiveness analysis, return on investment

A design thinking megközelítés széles körben elterjedt szemléletté vált az üzleti életben, és a közszférában is egyre inkább felismerik a jelentőségét. Mindezek ellenére vannak olyan piaci szegmensek és szereplök, akik mégsem részesítik elönyben az új koncepció által kínált eszközöket és módszereket. A design gondolkodásmód jellemzőinek részletezése után a cikk megoldási lehetőségeket vázol a szemlélet ágazatokon átivelő elterjedésének ösztönzésére, annak előnyeit számszerüsített formában

Vanda Orbulov is a PhD student at the University of Technology and Economics Faculty of Economic and Social Sciences, Department of Ergonomics and Psychology and Department of Management and Business Economics. E-mail: vanda.orbulov@erg.bme.hu 
történö bemutatásával. Rövid fogalmi tisztázást követően a cikk két fö témát ölel fel. Kutatási kérdés egyrészt, hogy befolyásolja-e a számszerüsitett hatékonyság a döntéshozókat a tervezési gondolkodásmód általános elterjedésének elösegitésében. Másodsorban három metrikát mutat be a hatékonyság kimutathatóságára a föbb jellemzők összehasonlításával. Végül a következtetések levonásával a kutatási kérdések értékelésére kerül sor.

JEL-klasszifikáció: A12, B49, D40, D47, D70, D79, L11, L20, L80, M10, M20, M30, O10, O20, O30

Kulcsszavak: design thinking, hatékonyság, service design, metrikák a design thinking szemléletre, relatív hatékonyságvizsgálat, költséghatékonysági elemzés, befektetésarányos megtérülés

\section{Introduction}

The design thinking approach is an often applied mindset that brings advantages for industrial and commercial activities as innovative concepts. ${ }^{1}$ In this article, design thinking as a mindset or approach covers all the points of view and related methods based on customer experiences, including the full scope of product development and product management.

After having experienced a severe expansion of design thinking attitude in several product segments, for some reason, it did not appear in other ones. Our research question intends to highlight the possible reason for this lack of demonstration: pure efficiency. Efficiency is a priority for all the systems. Without the quantification of the efficiency, the methods related to design thinking cannot spread to different industries and organisations in which it could have practical effects. However, relevant research determined that costumer-obsessed companies have the highest median three-year growth in sales, and the highest levels of customer satisfaction and employee satisfaction; a direct correlation between design thinking mindset and effectiveness, specific to the organisation, might be needed. The main point is the need for an accurate measurement based on one reliable method. An optimal harmonisation of several methods can clearly emphasise the quantified efficiency of design thinking for any product development focused not only on economic entities but also on public services.

The paper is structured as follows. First, we discuss the design thinking perspective, how design thinking has been developed primarily in businesses and public segments, with a precise definition of effectiveness. We continue by describing and introducing the possible optional methods used for defining the effectiveness of the design thinking aspect before the findings are presented. The paper details three main possible methods. All the methods will be introduced by highlighting its advantages and barriers for its full application in design thinking. The paper concludes with a discussion of the findings,

Hasso Plattner, Christoph Meinel and Larry Leifer (eds.), Design Thinking Research, Making Design Thinking Foundational (Heidelberg: Springer, 2016). 
conclusions, and implications for further research on design thinking application possibilities.

\section{Discussion on design thinking and efficiency}

Application of methods depends on their efficiency in many cases, while the spread of useful and innovative approaches, tools, and methods can have barriers because of the lack of tangible advantages of the methods.

\subsection{Conceptual clarifications and background}

To provide a comprehensive and detailed background for examined methods, the authors introduce the most relevant conceptual clarifications that are significantly based on the authors' literature research and former practical experiences.

\subsubsection{Design thinking}

After the first introduction of creative thinking in engineering in 1959, and the establishment of the science of design by Simon, artificial intelligence and cognitive science researcher in 1969. ${ }^{2}$ Some years later, design thinking appeared as a new, innovative concept, ${ }^{3}$ and it refers to design practice and competence and appears not only as a mindset but also as a practical problem-solving approach. A durable design thinking sees the product as a linear link between man and his environment. In reality, designers must think of man, his means, environment, and ways of thinking about, planning for, and manipulating himself and his surroundings as a non-linear, simultaneous, integrated, comprehensive whole. ${ }^{4}$ After the sciences, the humanities, and design had been contrasted under each aspect, Cross could come closer to highlight the main essence of design: the appropriate methods of design are modelling, pattern-formation, synthesis, while the values of design are practicality, ingenuity, empathy, and concern for 'appropriateness'. Cross was convinced that both design research and design education contribute to the development of design as a discipline. ${ }^{5}$

After Schön created the theories on reflection-in-action and published them in 1983, design research got a new impulse by challenging the leading rationalist paradigm. ${ }^{6}$ Expert designers are solution-focused, not problem-oriented. Impressive design behaviour is not only based on extensive problem analysis but also on adequate 'problem

Herbert A Simon, The Sciences of the Artificial (Cambridge: MIT Press, 1996).

Peter G Rowe, Design thinking (Cambridge: MIT Press, 1991).

Victor Papanek, Design for the Real World: Human Ecology and Social Change (Academy Chicago Publishers, 2005).

Nigel Cross, 'Designerly ways of knowing', Design Studies 3 (1982), 221-227.

Donald A Schön, The Reflective Practitioner: How Professionals Think in Action (Taylor \& Francis Ltd., 1995). 
scoping' and a focused or directed approach to gathering problem information and prioritising criteria. ${ }^{7}$

The British Design Council first introduced the double-diamond model of the design in 2005. The model focuses on finding the right problem and finding the right solutions to fulfilling human needs simultaneously. Design thinking has no single dedicated clear definition, but many fields customise the aspect differently; the easiest way to understand the approach is to have the practice, the application, and the experience. ${ }^{8}$ Cooper $^{9}$ highlighted a historical background of design research from its start in the 1960s and has got a broad role and application within innovation throughout society and industry. Developed countries shift from industrial manufacturing to knowledge work and service delivery; the role of innovation is extending. Businesses adopted the new method trusted in solving their complex problems in a new, creative and innovative way by this new approach. ${ }^{10}$ New insights and understanding of design thinking were provided, based on evidence from observation and investigation of design practice and more in-depth insight into how designers create things and systems. ${ }^{11}$ Customers could get closer to the management level and implement the innovation by applying the human-centred design thinking approach to every level of their organisation. ${ }^{12}$ Professionals, researchers, and managers recognised that design thinking could be applied effectively for design issues, but it is often used to explore and define business problems, products, and services. Design thinking has spread from the design community to various other fields. ${ }^{13}$ Beyond that, design thinking is preferred as applied to design problems; it also brought the businesses' design approach. Norman ${ }^{14}$ defines life as good if it is complex, rich, and rewarding if it is understandable, sensible and meaningful. Researchers were at the point that there is also an opportunity for human-centred design to be adopted outside the traditional design field in strategic innovation processes, ${ }^{15}$ regarding design practice competence. ${ }^{16}$ The innovative design process is closely related to the fact that knowledge generation from Design Thinking theory has a non-linear but circular structure. ${ }^{17}$

Nigel Cross, 'Expertise in design: an overview', Design Studies 25 (2004), 427-441.

Kees Dorst, 'Design problems and design paradoxes', Design Issues 22 (2006), 4-17.

Rachel Cooper, 'Design research - Its 50-year transformation', Design Studies 65 (2019), 6-17.

Tim Brown, 'Design thinking', Harvard Business Review, June 2008, 84-92.

Nigel Cross, Design Thinking: Understanding How Designers Think and Work (Oxford: Berg Publishers, 2011).

12 Tim Brown, Change by Design: How Design Thinking Transforms Organizations and Inspires Innovation (New York: HarperCollins Publishers, 2009).

13 Kees Dorst, 'The core of »design thinking« and its application', Design Studies 32 (2011), 521-532.

14 Don Norman, Living with Complexity (Cambridge: MIT Press, 2010).

15 Mieke van der Bijl-Brouwer and Kees Dorst, 'Advancing the strategic impact of human-centred design', Design Studies 53 (2017), 1-23.

16 Genevieve Moselya, Natalie Wright and Cara Wrigley: 'Facilitating design thinking: A comparison of design expertise', Thinking Skills and Creativity 27 (2018), 177-189.

17 Harah Chon and Josely Sim, 'From design thinking to design knowing: An educational perspective', Art, Design \& Communication in Higher Education 18 (2019), 187-200. 
Design is not one way of thinking: it is a mix of different thinking. Design Thinking can be variously defined from a diverse perspective. This mindset can be identified as a design methodology and an approach for innovation ${ }^{18}$ and a mix of different kinds of thinking. ${ }^{19}$ It differs from traditional design approaches in several ways, like the intense focus on the creativity and customer-centred processes. Design Thinking can be regarded as a problem-solving method or a procedure for resolving issues. It is suspected to be the right approach for the so-called ill-defined or wicked problems, either having defined issues or solutions. Design thinking puts much effort into problem-shaping, framing, ${ }^{20}$ and the phase of definition. Simon pointed out that the design transforms the existing conditions into the preferred ones. ${ }^{21}$

Design Thinking as a creativity approach focuses on the practical, analytical attitude, and emphasises the narrowing the design choices. According to Bäck and Gremett, ${ }^{22}$ Design Thinking is a more creative and user-centred attitude to problem-solving than other, former traditional design methods. The point is that understanding and defining the problems from a customer aspect are vital factors. ${ }^{23}$ The collaborative Design Thinking (CoDeT) approach was also mentioned as a progressed variety of the Design thinking attitude that also combines elements of Social Interdependence Theory (SIT) and Design Thinking as CoDeT through a case study. ${ }^{24}$ In this paper, design thinking as a robust process is described in line as a series of five iterative phases: empathise, define, ideate, prototype, and test, empathy having a highly significant role regarding the process. ${ }^{25}$ The design thinking aspect should have an influential role in essential business strategies, integrated deeply into the product development process, customer services, and employee incentives. Personalised, distinguished customer experience is a competitive advantage. Organisations and business entities have a human-centred approach by designing their products and services, increasing yearly income, and having higher customer satisfaction levels and brand loyalty. Competition is a more intensive, customer-focused mindset and is dominant mainly in segments where the entry barrier is low, and services are similar.

$18 \quad$ Plattner, Meinel and Leifer, Design Thinking Research.

19 Dorst, 'The core'.

20 Herbert A Simon, 'Problem forming, problem finding and problem solving in design', in Design and Systems, General Application of Methodology, ed. by Arne Collen (New Brunswick: Transaction Publishers, 1995), 245-257; Kees Dorst, Frame Innovation: Create New Thinking by Design (Cambridge: MIT Press, 2015).

21 Simon, The Sciences of the Artificial.

22 Peter Gremett and Aline Bäck, 'Design Thinking: Expanding UX Methods Beyond Designers', in UX Best Practices: How to Achieve More Impact with User Experience, ed. by Helmut Degen and Xiaowei Yuan (McGraw-Hill Osborne Media, 2011), 304.

23 Don Norman, The Design of Everyday Things (New York: Basic Books, 2013).

24 Maarten Van Mechelen, Ann Laenen, Bieke Zamand, Bert Willems and Vero Vanden Abeele, 'Collaborative Design Thinking (CoDeT): A co-design approach for high child-to-adult ratios', International Journal of Human-Computer Studies 130 (2019), 179-195.

25 Matthew Lynch, Uladzimir Kamovich, Kjersti K Longvaa, and Martin Steinert, 'Combining technology and entrepreneurial education through design thinking: Students' reflections on the learning process', Technological Forecasting and Social Change 164 (2021); Lori A Deitte and Reed A Omary, 'The Power of Design Thinking in Medical Education', Academic Radiology 26 (2019), 1417-1420.

Európai Tükör 2020/4. 


\subsubsection{Metrics for design thinking}

Traditional business metrics focus on the performance, measured quantitatively and objectively, based on shareholders' and stakeholders' interests and aspects. The fact is that business indicators can follow the customer experience by a time-shift, allowing a late intervention into affected processes.

The management and the customers' expectations are diverse: the board prefers to have loyalty, trust, and high customer lifetime value, while the customer wishes a smooth, customised, and fast solution for needs. Evaluation of customer experience might be based on reference points incorporated in the customer journey that covers the total numbers and types of interaction between the customer and representatives of the product or the service provider. Metrics specialised to brand loyalty and customer satisfaction can optionally be applied; organisations can also create their metrics-system for evaluating customer experiences. Net Promoter Score (NPS) and Customer Effort Score (CES) are significant factors of Customer Feedback Metrics (CFMs) focusing on customer satisfaction. Drawing of conclusions by combining CFMs is not only about customer satisfaction and possible customer experience but also about other relevant factors of business forecasts. ${ }^{26}$ NPS is widely used in the industry to evaluate customer loyalty and also to predict revenue growth. The revenue growth is based on promoter customers' favourable recommendation to potential customers, increasing purchases from the existing base of loyal customers. Moreover, NPS is considered a suitable metric for predicting revenue growth from the existing customer base. ${ }^{27}$ NPS is mainly calculated by a willingness to recommend a dedicated fixed scale of $0-10$, optionally completed by open questions to the interviewed customers. As a result of the scoring, detractors, passives, and promoters are differentiated, with a numerical difference of the ratio of supporters in percentage and the ratio of critics in percentage. The final value is between -100 and +100 ; organisations aim the positive value range. CES is a metric that evaluates the effort a customer has to apply to use or buy a product or service, find the needed information, or resolve an issue. CES is usually measured through a five or 7-degree scale with extreme values, but any other creative and visual solutions can also be introduced. Practically, in case of negative answers, as with NPS, an optional question might be asked to understand the interviewed customer more deeply. ${ }^{28} \mathrm{~A}$ high CES indicates that customers find an easy and effortless interaction in low-value processes aimed at interactions that should be reconsidered.

On the one hand, integrating immediate feedback into the product development processes could also positively impact business indicators, usually calculated some months later. On the other hand, declaring the effectiveness of the application of design thinking contributes to the spread of this mindset, affecting the whole operation.

\footnotetext{
26 Evert de Haan, Peter C Verhoef, and Thorsten Wiesel, 'The predictive ability of different customer feedback metrics for retention', International Journal of Research in Marketing 32 (2015), 195-206.

27 Philip Mecredy, Malcolm J.Wright, and Pamela Feetham, 'Are promoters valuable customers? An application of the net promoter scale to predict future customer spend', Australasian Marketing Journal 26 (2019), 3-9.

28 Ludvík Eger and Michal Mičík, 'Customer-oriented communication in retail and Net Promoter Score', Journal of Retailing and Consumer Services 35 (2017), 142-149.
} 


\subsubsection{Effectiveness}

Effectiveness is a kind of basis in every organisation. An organisation is effective if it achieves a specific goal with the least possible expenditure or with a specific expense to achieve maximum results. Effectiveness is a measurable concept, strictly precisely and quantitatively determined. In some cases, efficacy and efficiency are interpreted as a synonym of effectiveness. An organisation can be effective if it achieves its results by optimising available resources. ${ }^{29}$

Effectiveness became a crucial technological fact in modern industrial society, it is still in focus for contemporary engineering, and it remains fundamental in both industrial and post-industrial contexts. ${ }^{30}$ The traditional research pipeline was defined as efficacy - effectiveness - implementation as opposed to hybrid designs that combine effectiveness and implementation research elements, ensuring both effectiveness and implementation outcomes within a study. ${ }^{31}$

\subsection{Methods and aspects}

The introduced methods and aspects are well-known in diverse kinds of academic and economic segments, applied successfully, and supposed to adapt to the design thinking practice.

\subsubsection{Data envelopment analysis}

Data envelopment analysis (DEA) is a nonparametric method used for technical effectiveness. According to the previously highlighted definition, ${ }^{32}$ DEA can be applied as an appropriate scoring method, based on two or more evaluation criteria. Performance data are transformed into a scale and an aggregate score calculated by applying weights. DEA is applied successfully by integrating different aspects into aggregated indicators.

$29 \quad$ Rita Veronika Dénes, Tamás Koltai and Zoltán Dénes, 'A betegek állapotát is figyelembe vevő relatív hatékonyságvizsgálat (DEA) a hazai mozgásszervi rehabilitációs osztályokon I. rész’ [Data envelopment analysis (DEA) taking into account the condition of patients of the domestic rehabilitation departments, part I], IME (Interdiszciplináris Magyar Egészségügy) 17, no 4 (2018), 40-44; Rita Veronika Dénes, Tamás Koltai and Zoltán Dénes, 'A betegek állapotát is figyelembe vevő relatív hatékonyságvizsgálat (DEA) a hazai mozgásszervi rehabilitációs osztályokon II. rész' [Data envelopment analysis (DEA) taking into account the condition of patients of the domestic rehabilitation departments, part II], IME (Interdiszciplináris Magyar Egészségügy) 17, no 5 (2018), 31-34.

30 Jennifer K Alexander: 'The Concept of Efficiency: An Historical Analysis', in Philosophy of Technology and Engineering Sciences (Handbook of The Philosophy of Science), ed. by Anthonie Meijers (New York: Elsevier, 2009), 1007-1030.

31 Sara J Landes, Sacha A McBain and Geoffrey M Curran, 'An introduction to effectiveness-implementation hybrid designs'. Psychiatry Research 280 (2019).

32 Tamás Koltai, Sebastián Lozano, Judit Uzonyi-Kecskés and Plácido Moreno, 'Evaluation of the results of a production simulation game using a dynamic DEA approach', Computers \& Industrial Engineering 105 (2017), 1-11. 
When it comes to comparing different organisations' performance, there is usually no single indicator that defines all essential organisational unit performance elements. Moreover, indicators are generally in different dimensions (these data are of different units, like income, customer satisfaction, or brand awareness). The composition of the resources used is often different: resources are applied for product development processes in different units and sectors, some companies optimise for human resources, other organisations believe in technology or skills of external partners in market researches. The purpose of the DEA is to compare departments performing the same activity based on the weight of the departments' outputs along with the inputs applied for it. While outputs define the organisational units' results, inputs explain resources used for achieving output-results stated by management decisions. An essential feature of an organisational unit is that it controls the number of inputs for achieving outputs. Depending on this feature, organisational units are referred to as decision-making units or DMUs (Decision Making Units). From this perspective, the DEA method can be applied by defining the product development department or team of an organisation as DMUs. The first observed DMU is applying design thinking methods, likewise representing a design thinking perspective, and another DMU is not using the tools provided by these processes.

Inputs are the amount of time spent for a product development process and the number of FTE (full-time employee). Outputs are the number of the tested prototypes.

The basis for comparing DMUs is the weighted sum of the outputs to the inputs' weighted sum. Weights are not subjective but determined by specific mathematical tools, based on the characteristics. The units' characteristics of weighted inputs to weighted outputs can be calculated in many ways. We hypothesise that the output-oriented approach dominates in most cases relevant for our research so that the goal of the DMUs' managements is to produce as much output (for example, tested prototypes) as possible at the present value of the inputs. The sum of the weighted inputs is divided by the weighted outputs' sum when calculating the efficiency indicator. Severely decreased time- and human resource requirement of the product development process and significantly increased number of customer-focused conceptions or tested prototypes, are the important effects of design thinking approach. It shows obviously that fixed inputs (human resources) could produce more outputs (tested prototypes). The efficiency indicator calculated in this way expresses the extent to which outputs (the number of customer-focused conception or tested prototypes) be increased to efficiently use the amount of current input (the amount of spent time for a product development process or the number of FTE). The mathematical methods of relative efficiency testing are based on the application of linear programming.

However, the DEA scoring method can bring significant results by specifying efficiency among DMUs with the same activities. It is practically challenging to define the soft facts (weights) relevant to the differentiation, especially in economic organisations and public service providers. Nevertheless, DEA enables the application of sophisticated viewpoints that can contribute to the correct result (a financial situation, skills, location, legal environment, IT architecture). 


\subsubsection{Return on Investment}

Return on Investment (ROI) is optimised for monetary units referred to the income and outcome. ROI is a performance measure used to evaluate the efficiency of an investment or compare projects and investments. As its calculation, the benefit of the Investment must be divided by the investment cost, and the result is determined in percentage or ratio. ${ }^{33}$

For adopting the efficiency of applying the design thinking mindset, the transformation of customer satisfaction units should be performed into numerical data, able to express costs and benefits. Advantages expressed in monetary units realised by applying design thinking aspects during the business operation and development processes can be compared to additional costs. Defining the efficiency of the customer experience approach contrasts the operation without design thinking.

Contradictions could be observed by connecting ROI and metrics applied practically for a design thinking mindset. Improvement of the customer experience, managed as an independent project at most of the organisations that open for the design thinking aspect.

\subsubsection{Cost-effectiveness analysis}

Although cost-effectiveness (CE) analysis focuses mainly on the healthcare and its decision-making, ${ }^{34}$ the analysis could also be adopted for determining the effectiveness of other segments, sectors where transparent and objective comparison of the cost and the related benefits are needed. In CE analysis, costs of investments are compared with outcomes measured in other units, for example, tested prototypes, satisfied employees and customers, increasing incomes and profits, brand awareness. Usually, costs can be expressed in monetary units but not the benefits in many cases. CE analysis allows benefits to be measured in their units to contribute to a complete range of outcomes. $\mathrm{CE}$ is calculated by splitting the ratio of efficiency by the investment cost - as the direct ratio of the benefits to the costs. Definition of CE, costs, or efficiency are consistent compared to the examined alternatives. ${ }^{35}$

The specificity of the analysis is currently the application practice for public services, especially for healthcare projects, and focuses on introducing new treatments and processes. Elements of the analysis might be adopted into a comparing business model applied explicitly to our focus topic: measurement of units using a design thinking mindset and units not using such. Consequently, the analysis might be applied for the comparison issue, focusing on the effectiveness of new processes.

\footnotetext{
33 M Paul Pandian, RFID for Libraries, A Practical Guide (Oxford: Chandos Publishing, 2010), 133-149.

34 MC Weinstein and WB Stason, 'Foundations of Cost-Effectiveness Analysis for Health and Medical Practices', The New England Journal of Medicine 296 (1977), 716-721; Louise B Russell, Marthe R Gold, Joanna E Siegel, et al.: 'The Role of Cost-effectiveness Analysis in Health and Medicine', JAMA American Medical Association 276 (1996), 1172-1177.

35 JD Fletcher, 'Cost Analysis in Evaluation Studies', in International Encyclopedia of Education (Burlington: Elsevier, 2010), 585-591.
} 


\subsubsection{Improvement opportunities regarding the current introduced methods}

The summarised overview of the above optional methods regarding the main factors of their usability can be seen below as the conclusion on the examined methods (Table 1).

Table 1

Conclusion on the examined methods

\begin{tabular}{|c|c|c|c|}
\hline Method & $\begin{array}{c}\text { Name of lis- } \\
\text { ted method }\end{array}$ & $\begin{array}{c}\text { Ranking of its adap- } \\
\text { tion for evaluation of } \\
\text { the design thinking's } \\
\text { effectiveness* }\end{array}$ & $\begin{array}{c}\text { Conversion needed in details } \\
\text { (main points) }\end{array}$ \\
\hline Method 1 & $\begin{array}{c}\text { Data envelop- } \\
\text { ment analysis }\end{array}$ & 1 & $\begin{array}{c}\text { Clear definition of soft factors, } \\
\text { adapting to the analysis. }\end{array}$ \\
\hline Method 2 & $\begin{array}{c}\text { Return on } \\
\text { Investment }\end{array}$ & 3 & $\begin{array}{c}\text { Resolution of the contradiction of } \\
\text { pure business aspect and factors of } \\
\text { customer experience; } \\
\text { Transformation of non-numerical } \\
\text { data into monetary data }\end{array}$ \\
\hline Method 3 & $\begin{array}{c}\text { Cost- } \\
\text { effectiveness } \\
\text { analysis }\end{array}$ & 2 & $\begin{array}{c}\text { The analysis applied by health- } \\
\text { care, education sector, and public } \\
\text { services; } \\
\text { the method should be transformed } \\
\text { into a comparative business aspect } \\
\text { instead of focusing on a single } \\
\text { process. }\end{array}$ \\
\hline
\end{tabular}

*1 - optimal option; 2 - can be used with compromises; 3 - difficult to adapt

Source: edited by the authors

\section{Conclusion}

Design Thinking mindset might be the most relevant differentiating factor in the next years. Organisations and profit-oriented companies, regardless of the sector they operate in, pursuing an approach of customer-oriented focus, will have a definite competitive advantage. However, measurement and monitoring of customer experience are crucial in applying the design thinking mindset; customer-focus should appear on a strategic level supported by a highly engaged management. A customer-oriented strategy is not a fixed but a dynamic, developing guide for all the organisation's employees. Adaptation of the design thinking approach should be interpreted as benefits realised as a business investment, by having a formal calculated return on investment or cost-effectiveness analysis. Effectiveness of a design thinking mindset should be expressed in a similar way to those already successfully applied in the business practice, in order to be able to make the right decisions. One relevant finding is that the approach and its tools are 
genuinely practical in several segments and organisations. Still, effectiveness should also be illustrated by numerical outcomes of analyses which have been well applied to current projects and investments. Analyses should also highlight differences of units applying the design thinking approach and those that do not. Another significant finding is that transformation of introduced methods is necessary.

\section{References}

Alexander, Jennifer K: 'The Concept of Efficiency: An Historical Analysis'. In Philosophy of Technology and Engineering Sciences (Handbook of The Philosophy of Science), ed. by Anthonie Meijers. New York, Elsevier, 2009, 1007-1030. Online: https://doi. org/10.1016/B978-0-444-51667-1.50041-0

Brown, Tim: Change by Design: How Design Thinking Transforms Organizations and Inspires Innovation. New York, HarperCollins Publishers, 2009.

Brown, Tim: 'Design thinking'. Harvard Business Review, June 2008, 84-92.

Chon, Harah - Josely Sim: 'From design thinking to design knowing: An educational perspective'. Art, Design \& Communication in Higher Education 18 (2019), 187-200. Online: https://doi.org/10.1386/adch_00006_1

Cooper, Rachel: 'Design research - Its 50-year transformation'. Design Studies 65 (2019), 6-17. Online: https://doi.org/10.1016/j.destud.2019.10.002

Cross, Nigel: 'Designerly ways of knowing'. Design Studies 3 (1982), 221-227. Online: https://doi.org/10.1016/0142-694X(82)90040-0

Cross, Nigel: 'Expertise in design: an overview'. Design Studies 25 (2004), 427-441. Online: https://doi.org/10.1016/j.destud.2004.06.002

Cross, Nigel: Design Thinking: Understanding How Designers Think and Work. Oxford, Berg Publishers, 2011. Online: https://doi.org/10.5040/9781474293884

De Haan, Evert - Peter C Verhoef - Thorsten Wiesel: 'The predictive ability of different customer feedback metrics for retention'. International Journal of Research in Marketing 32 (2015), 195-206. Online: https://doi.org/10.1016/j.ijresmar.2015.02.004

Deitte, Lori A and Reed A Omary: 'The Power of Design Thinking in Medical Education'. Academic Radiology 26 (2019), 1417-1420. Online: https://doi.org/10.1016/j. acra.2019.02.012

Dénes, Rita Veronika - Tamás Koltai - Zoltán Dénes: 'A betegek állapotát is figyelembe vevő relatív hatékonyságvizsgálat (DEA) a hazai mozgásszervi rehabilitációs osztályokon I. rész' [Data envelopment analysis (DEA) taking into account the condition of patients of the domestic rehabilitation departments, part I]. IME (Interdiszciplináris Magyar Egészségügy) 17, no 4 (2018), 40-44.

Dénes, Rita Veronika - Tamás Koltai - Zoltán Dénes: 'A betegek állapotát is figyelembe vevő relatív hatékonyságvizsgálat (DEA) a hazai mozgásszervi rehabilitációs osztályokon II. rész' [Data envelopment analysis (DEA) taking into account the condition of patients of the domestic rehabilitation departments, part II]. IME (Interdiszciplináris Magyar Egészségügy) 17, no 5 (2018), 31-34.

Dorst, Kees: 'Design problems and design paradoxes'. Design Issues 22 (2006), 4-17. Online: https://doi.org/10.1162/desi.2006.22.3.4. 
Dorst, Kees: Frame Innovation: Create New Thinking by Design. Cambridge, MIT Press, 2015. Online: https://doi.org/10.7551/mitpress/10096.001.0001

Dorst, Kees: 'The core of »design thinking « and its application'. Design Studies 32 (2011), 521-532. Online: https://doi.org/10.1016/j.destud.2011.07.006.

Eger, Ludvík - Michal Mičík: 'Customer-oriented communication in retail and Net Promoter Score'. Journal of Retailing and Consumer Services 35 (2017), 142-149. Online: https://doi.org/10.1016/j.jretconser.2016.12.009

Fletcher, JD: 'Cost Analysis in Evaluation Studies'. In International Encyclopedia of Education. Burlington, Elsevier, 2010. 585-591. Online: https://doi.org/10.1016/B978-008-044894-7.01607-9

Gremett, Peter - Aline Bäck: 'Design Thinking: Expanding UX Methods Beyond Designers'. In UX Best Practices: How to Achieve More Impact with User Experience, ed. by Helmut Degen and Xiaowei Yuan. McGraw-Hill Osborne Media, 2011.

Koltai, Tamás - Sebastián Lozano - Judit Uzonyi-Kecskés - Plácido Moreno: 'Evaluation of the results of a production simulation game using a dynamic DEA approach'. Computers \& Industrial Engineering 105 (2017), 1-11. Online: https://doi.org/10.1016/j. cie.2016.12.048

Landes, Sara J - Sacha A McBain - Geoffrey M Curran: 'An introduction to effectiveness-implementation hybrid designs'. Psychiatry Research 280 (2019). Online: https://doi.org/10.1016/j.psychres.2019.112513

Lynch, Matthew - Uladzimir Kamovich - Kjersti K Longva - Martin Steinert: 'Combining technology and entrepreneurial education through design thinking: Students' reflections on the learning process'. Technological Forecasting and Social Change 164 (2021). Online: https://doi.org/10.1016/j.techfore.2019.06.015

Mecredy, Philip - Malcolm J Wright - Pamela Feetham: 'Are promoters valuable customers? An application of the net promoter scale to predict future customer spend'. Australasian Marketing Journal 26 (2019), 3-9. Online: https://doi.org/10.1016/j. ausmj.2017.12.001

Moselya, Genevieve - Natalie Wright - Cara Wrigley: 'Facilitating design thinking: A comparison of design expertise'. Thinking Skills and Creativity 27 (2018), 177-189. Online: https://doi.org/10.1016/j.tsc.2018.02.004

Norman, Don: The Design of Everyday Things. New York, Basic Books, 2013.

Norman, Don: Living with Complexity. Cambridge, MIT Press, 2010.

Pandian, M Paul: RFID for Libraries, A Practical Guide. Oxford, Chandos Publishing, 2010. DOI: https://doi.org/10.1533/9781780630489

Papanek, Victor: Design for the Real World: Human Ecology and Social Change. Academy Chicago Publishers, 2005.

Plattner, Hasso - Christoph Meinel - Larry Leifer (eds.): Design Thinking Research, Making Design Thinking Foundational. Heidelberg, Springer, 2016. Online: https:// doi.org/10.1007/978-3-319-19641-1

Rowe, Peter G: Design thinking. Cambridge, MIT Press, 1991.

Russell, Louise B - Marthe R Gold - Joanna E Siegel et al.: 'The Role of Cost-effectiveness Analysis in Health and Medicine'. JAMA American Medical Association 276 (1996), 1172-1177. Online: https://doi.org/10.1001/jama.1996.03540140060028 
Schön, Donald A: The Reflective Practitioner: How Professionals Think in Action. Taylor \& Francis Ltd., 1995.

Simon, Herbert A: 'Problem forming, problem finding and problem solving in design'. In Design and Systems, General Application of Methodology, ed. by Arne Collen. New Brunswick, Transaction Publishers, 1995, 245-257.

Simon, Herbert A: The Sciences of the Artificial. Cambridge, MIT Press, 1996.

Van der Bijl-Brouwer, Mieke - Kees Dorst: 'Advancing the strategic impact of human-centred design'. Design Studies 53 (2017), 1-23. Online: https://doi.org/10.1016/j.destud.2017.06.003.

Van Mechelen, Maarten - Ann Laenen - Bieke Zaman - Bert Willems - Vero Vanden Abeele: 'Collaborative Design Thinking (CoDeT): A co-design approach for high child-to-adult ratios'. International Journal of Human-Computer Studies 130 (2019), 179-195. Online: https://doi.org/10.1016/j.ijhcs.2019.06.013

Weinstein, MC - WB Stason: 'Foundations of Cost-Effectiveness Analysis for Health and Medical Practices'. The New England Journal of Medicine 296 (1977), 716-721. Online: https://doi.org/10.1056/NEJM197703312961304 